\title{
Development of Cultural and Creative Design of Regional Souvenirs
}

\author{
Guochao Zang \\ Department of Art and Design, Guangzhou Institute of Technology, Guangzhou, Guangdong, China, 510075 \\ 25512800@qq.com
}

Keywords: regionalism; souvenirs; cultural and creative design

\begin{abstract}
As an important part of tourism, souvenirs undertake the important task of spreading and publicizing regional culture. On this basis, this paper makes a brief introduction to the background of cultural and creative design development of regional souvenirs, and puts forward relevant designing and development strategies to bring some enlightenment to relevant professionals.
\end{abstract}

\section{Introduction}

Preface: Souvenir is the concentrated reflection of regional featured culture, and it can deepen the understanding of tourists to cultural features and local customs and conditions of the scenic area, while souvenir also have the capacity of breaking the limitation of time and space, continuing and expanding spreading routes of regional culture at the same time, which can provide supports for further development of tourism in different places in China. So the study on the development of cultural and creative design of souvenirs have higher realistic significance.

\section{Background of Cultural and Creative Design Development of Regional Souvenirs}

In recent years, cultural and creative industries both at home and abroad have realized great development. While with the rising of gross domestic products in China, the rapid growth of economy also provides sufficient development opportunity for cultural and creative products in China. It is shown in table 1 about the comparison of the development conditions of tourism of Hunan in 2004 and 2017. We can find through the table that in recent years, tourism in Hunan has realized great development, while most areas in China also have such development. The development of tourism puts forward higher demand to souvenirs with high quality, so cultural and creative industry can develop deep cooperation with tourism[1].

Table 1 Comparison of the development conditions of tourism of Hunan in 2004 and 2017

\begin{tabular}{ccc}
\hline Index & 2004 & 2017 \\
\hline Domestic tourist population(hundreds of million) & 1.53 & 2.53 \\
Domestic tourist income(hundreds of million yuan) & 789 & 2000 \\
Immigration population(hundreds of million) & 0.243 & 0.45 \\
Foreign exchange earned through tourism(hundreds of million dollars) & 124 & 458 \\
\hline
\end{tabular}

It is found in actual investigation of the writer that although in recent years, tourism in China develops rapidly, cultural and creative design market of tourist souvenir in China has problems that can't be neglected for long term such as similar design, mutual copy, unclear regional features, etc. Design of tourist souvenir lacks cultural connotation, sales of tourist souvenir in different scenic areas form bad competition. All these problems are common, and the treatment of these problems concerns about the further development of tourism in China. 


\section{Development Strategy of Cultural and Creative Design of Regional Tourist Souvenir}

\subsection{Concern about the basic spirit of cultural and creative design}

Cultural and creative design of regional tourist souvenir must pay attention to the basic spirit including regionalism and peculiarity, and specific concerning contents are as following: (1) Regionalism. Regionalism requires that cultural and creative design shall adapt to local demand, so different places must combine their own cultural features and the development of cultural and creative design of tourist souvenir together. The unique tourist attraction and historic allusions of different places shall become the aspiration of cultural and creative design. (2) Peculiarity. To guarantee the peculiarity of tourist souvenir, designers must explore consumer's psychology of tourist group, envisage local tourist feature, and explore local culture focusing on cultural and creative design so that they can better pay attention to the basic spirit of cultural and creative design, and meet the development requirement of tourism in different places.

\subsection{Pay attention to abstraction of regional featured elements}

To develop cultural and creative design of regional souvenir pointedly, designers should also pay attention to abstraction of regional features. Table 2 shows regional featured elements abstracted from the development of regional tourist souvenir in Shenyang, Liaoning, and the designer grasps regional features of Shenyang, and selects totem of crow tribe and flag color of eight banners in Manchu for development of regional souvenir. The application of image and color symbolizing nationality enhance the cultural nature and regionalism of tourist souvenir greatly. It is visible that the abstraction of regional featured element provides supports for the development of cultural and creative design of tourist souvenir[2].

Table 2 Regional featured elements of Shenyang, Liaoning

\begin{tabular}{cc}
\hline Regional featured elements & Specific contents \\
\hline Manchu image & $\begin{array}{c}\text { Riding and shooting image, custom image, image } \\
\text { of animal and plant }\end{array}$ \\
Color element & Color of eight banner of Manchu, color used \\
commonly in civil
\end{tabular}

\subsection{Adopt scientific designing methods}

Table 3 Analysis of development orientation of cultural and creative design of Xiangfei bamboo bracelet in Hunan

\begin{tabular}{cc}
\hline Orientation & Specific design \\
\hline $\begin{array}{c}\text { Crowd orientation } \\
\text { orientation }\end{array}$ & $\begin{array}{c}\text { Young lovers aged from } 20 \text { to 30; } \\
\text { Elegant, top-end, delicate; }\end{array}$ \\
$\begin{array}{c}\text { Functional orientation } \\
\text { It can be worn with spiritual ballast and emotional factor of acceptance, } \\
\text { designing feeling, material aesthetics. Regional cultural story of Xiangfei } \\
\text { bamboo is better penetrated and designed; }\end{array}$ \\
$\begin{array}{c}\text { Top-end, medium, and low-end with the price from RMB } 120 \text { to 1800; } \\
\text { Shape orientation } \\
\text { Market of tourist lovers }\end{array}$ \\
\hline
\end{tabular}


Table 4 Development method of cultural and creative design of souvenirs

\begin{tabular}{cc}
\hline Direction & Specific methods \\
\hline Policy & $\begin{array}{c}\text { Cultivate urban personality, shape image, and construct mark; } \\
\text { Build development alliance of souvenir and brand reputation system; } \\
\text { Explore and apply local culture; } \\
\text { Culture }\end{array}$ \\
Combine with local festival and custom; \\
Advocate local advantage; \\
Behavior & $\begin{array}{c}\text { Develop cultural and creative design of souvenir combining with experiential tourist } \\
\text { consumption mode; }\end{array}$ \\
Geography & Compose urban chain, and assist to develop cultural and creative design of regional \\
& souvenir;
\end{tabular}

The development of cultural and creative design of regional tourist souvenir can't leave support of scientific designing method. Table 3 is the analysis of development orientation of cultural and creative design of Xiangfei bamboo bracelet in Hunan. Combining with the table, it can be found that the design and development of the tourist souvenir Xiangfei bamboo bracelet pays close attention to the marketing demand of tourism, and at the same time, the penetration of the cultural connotation of Xiangfei bamboo also lets regional culture be displayed perceptually. It should be noticed that the application of scientific designing method must consider the shape, function, artificial technology, application, cultural penetration of tourist souvenir comprehensively so that it can guarantee that relevant tourist souvenir can better serve for the development of local tourism. Table 4 is the development method of cultural and creative design of tourist souvenir that is confirmed by some place focusing on policy, culture, behavior and geography. The method provides support for the development of creative and cultural design of regional souvenir, and relevant contents have higher references.

\section{Conclusion}

Above all, the development of cultural and creative design of souvenirs have higher realistic significance. While on this basis, contents that are mentioned in this paper such as concerning about the basic spirit of cultural and creative design, emphasizing abstraction of regional featured elements, adopting scientific designing methods certify the high practical value of the study. So in relevant theoretical study and practical exploration of cultural and creative design of souvenirs, this paper can play a certain role of reference.

\section{References}

[1] Chiou S C, Wang Y C. The example application of genetic algorithm for the framework of cultural and creative brand design in Tamsui Historical Museum[J]. Soft Computing, 2017:1-19.

[2] Hay L. Creative design engineering: introduction to an interdisciplinary approach[J]. Journal of Engineering Design, 2017, 28(2):144-146.

[3] Hachemvermette C. Multistory building envelope: Creative design and enhanced performance[J]. Solar Energy, 2018, 159:710-721.

[4] Hao J, Zhou Y, Zhao Q, et al. An evolutionary computation based method for creative design inspiration generation[J]. Journal of Intelligent Manufacturing, 2017(6):1-19. 